\title{
"Tax incentives as a factor of effective development of domestic tourism industry in Russia"
}

\begin{tabular}{|c|c|}
\hline AUTHORS & $\begin{array}{l}\text { Aleksandr Gudkov } \text { http://orcid.org/0000-0002-4006-4522 } \\
\mathbb{R} \text { http://www.researcherid.com/rid/H-7717-2016 } \\
\text { Elena Dedkova (D http://orcid.org/0000-0003-3392-2952 } \\
\mathbb{R} \text { http://www.researcherid.com/rid/J-4234-2017 } \\
\text { Kristina Dudina (D http://orcid.org/0000-0001-5113-7021 } \\
\mathbb{R} \text { http://www.researcherid.com/rid/A-6764-2016 }\end{array}$ \\
\hline ARTICLE INFO & $\begin{array}{l}\text { Aleksandr Gudkov, Elena Dedkova and Kristina Dudina (2017). Tax incentives } \\
\text { as a factor of effective development of domestic tourism industry in Russia. } \\
\text { Problems and Perspectives in Management, 15(2), 90-101. } \\
\text { doi:10.21511/ppm.15(2).2017.09 }\end{array}$ \\
\hline DOI & http://dx.doi.org/10.21511/ppm.15(2).2017.09 \\
\hline RELEASED ON & Thursday, 08 June 2017 \\
\hline RECEIVED ON & Thursday, 02 February 2017 \\
\hline ACCEPTED ON & Thursday, 16 March 2017 \\
\hline LICENSE & $\begin{array}{l}(c) \text { EY } \\
\text { This work is licensed under a Creative Commons Attribution } 4.0 \text { International } \\
\text { License }\end{array}$ \\
\hline JOURNAL & "Problems and Perspectives in Management" \\
\hline ISSN PRINT & $1727-7051$ \\
\hline ISSN ONLINE & $1810-5467$ \\
\hline PUBLISHER & LLC "Consulting Publishing Company "Business Perspectives" \\
\hline FOUNDER & LLC "Consulting Publishing Company "Business Perspectives" \\
\hline
\end{tabular}

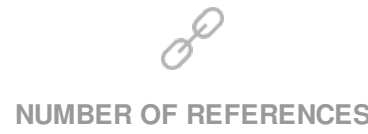

19
NUMBER OF FIGURES

4

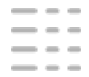

NUMBER OF TABLES

4

(C) The author(s) 2023. This publication is an open access article. 


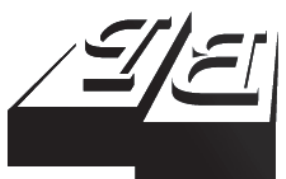

BUSINESS PERSPECTIVES

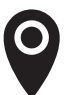

LLC "CPC "Business Perspectives" Hryhorii Skovoroda lane, 10, Sumy, 40022, Ukraine

www.businessperspectives.org
Received on: $2^{\text {nd }}$ of February, 2017 Accepted on: $16^{\text {th }}$ of March, 2017

(C) Aleksandr Gudkov, Elena Dedkova, Kristina Dudina, 2017

Aleksandr Gudkov, Ph.D. in Economics, Assistant Professor of the Department of Accounting and Audit, Orel State University, Russia.

Elena Dedkova, Ph.D. in Economics, Assistant Professor of the Departmen of Accounting and Audit, Orel State University, Russia.

Kristina Dudina, Assistant of the Department of Accounting and Audit, Orel State University, Russia.

\section{(c) (i)}

This is an Open Access article, distributed under the terms of the Creative Commons Attribution 4.0 International license, which permits unrestricted re-use, distribution, and reproduction in any medium, provided the original work is properly cited.

\section{TAX INCENTIVES AS A FACTOR OF EFFECTIVE DEVELOPMENT OF DOMESTIC TOURISM INDUSTRY IN RUSSIA ${ }^{1}$}

\begin{abstract}
In the recent period, of significant importance is the topic of ensuring national security, which is based, in particular, on the possibilities of existence of economic systems under the conditions of isolation, the maximum use of one's own internal resources to ensure import substitution. One of the types of such resources is recreational resources, which can be of interest both for the country's citizens and foreign citizens. However, a significant impact of geopolitical problems on the development of the tourism industry makes it possible to effectively calculate and most objectively forecast revenues only from its internal component. In this regard, the problem of development of the domestic tourism industry is becoming increasingly relevant with a view to making a positive impact of the sector's development on the welfare of the state as a whole and the creation of a favorable social climate for citizens. This article, on the basis of the methods of theoretical and empirical research, studies the peculiarities of development of the domestic tourism industry in Russia and examines the need in tax incentives for its effective development. Based on the analysis of the current state of the domestic tourism industry in Russia, the authors propose a division of the subjects of the tourism market, which are targeted by tax incentives, a new system for classifying domestic enterprises indicating the basic requirements and conditions for obtaining support, as well as specific measures of organizational and fiscal provisions for the growth of the domestic tourism market.
\end{abstract}

\section{Keywords}

economy, tourism, domestic tourism, taxes, tax incentives

\section{JEL Classification $\quad$ L83, H21}

\section{INTRODUCTION}

Problem statement. Tourism is one of the most promising and profitable sectors of the economy, while the tourism industry, as a branch of the national economy, has a huge impact on the indicators of the welfare and prosperity of the country both economically and socially. The key problem of development of the domestic tourism industry in Russia is related to the lack of incentives for the market participants, mainly related to economic and taxation fields, which make this sphere unprofitable from the point of view of investments and obtaining of a stable and high entrepreneurial income and, as a consequence, of the growth of its share in the country's GDP.

1 The article was prepared within the framework of realization of the grant of the President of the Russian Federation for the state support of young Russian scientists Ph.D. MK937.2017.6 on the topic "Development of measures of tax incentives and accounting provisions for the development of the domestic tourism industry in Russia" 
Analysis of the recent research and publications. The issues of the economy and state regulation of tourism were studied by the leading foreign and national scientists: E. Inskeep (1997), J. Tribe (2011), N. Vanhove (2010), S. Bystrov (2016), E. Dmitrieva (2010) and V. Yanyushkin (2012).

E. Inskeep thought that the importance of effective tourism planning in ensuring economic benefit and sustainability is now widely recognized. His work introduces concepts of national and regional tourism planning and looks at the basic approaches, techniques and principles applied at this level. Tourism must be developed and managed in a controlled, integrated and sustainable manner (Inskeep, 1997).

J. Tribe's edition is particularly overshadowed by the (near) global recession and its effect on recreation, leisure and tourism. The author agrees that it is impossible to predict the economic conditions that will prevail in the year when or the region where this book will be read. But it is important to understand what has happened over the course of economic business cycles to prepare for what may happen in the future. The important key topics of the book include: what are the economic impacts of leisure and tourism or how can economics be used to manage leisure and tourism? (Tribe, 2011).

N. Vanhove's book provides a succinct guide to the economic aspects of tourism for students and practitioners alike to decipher the methods of measurement of supply, demand, trends and impacts.In nine chapters the author gives the economic characteristic of the tourism sector, to methods of measurement, tourism demand and supply, impacts and forecasting all with the focus on tourism destinations. International case studies are used throughout including tourism surveys in the UK and other European countries (Vanhove, 2010).

S. Bystrov widely considers the importance of domestic tourism for the socio-economic system of the country and its regions. In his work, he examines the statistical data and the results of marketing researches of the last years that give an idea of the trends of development of domestic tourism in the Russian Federation and analyze the mechanisms for managing and coordinating the development of do- mestic tourism in the Russian Federation at the state level (Bystrov, 2016).

E. Dmitrieva, in her scientific work, pays attention to the role of state regulation in increasing the level of competitiveness of the tourist cluster with an example of the Nizhny Novgorod region of Russia (Dmitrieva, 2010).

V. Yanyushkin analyzes the financing of the tourism sector, including within the framework of federal targeted programs, and their combined impact on the development of the hotel services market in Russia. He also makes a short assessment of the influence of the Olympic Games on the development of the tourist cluster and its further effectiveness (Yanyushkin, 2012).

Theoretical, methodological and applied questions of stimulation, including tax stimulation, of entrepreneurial activity are reflected in the works of S. Kask, T. Kull and K. Orru (2016), R. Wehrli, H. Egli, M. Lutzenberger, D. Pfister, J. Stettler (2012), O. Kozmenko, O. Poluliakhova, O. Iastremska (2015), O. Kaurova (2013), V. Krivoruchko (2011), A. Varvashtian (2011), Y. Markova (2011), D. Rotanova (2016) and others.

S. Kask, T. Kull, K. Orru and also Roger Wehrli, Hannes Egli, Martin Lutzenberger, Dieter Pfister, Jürg Stettler made big researches in the field of sustainable tourism. The goal of their studies to was learn more about tourists' understanding of sustainable tourism and understanding of it by Russian tourist managers. The empirical survey with over 6,000 respondents in eight countries identifies the most relevant aspects of sustainable tourism from the tourists' perspective. The paper by S. Kask, T. Kull, K. Orru adopts the concept of sustainable tourism as defined in the United Nations guide for sustainable strategy building. Sustainable tourism is understood as 'tourism that respects local people and travellers, cultural heritage and the environment'. In order to develop a feasible strategy for sustainable tourism planning it is vital to take into account the most important key components (Kask et al., 2016; Wehrli et al., 2012).

The paper by O. Kozmenko, O. Poluliakhova, O. Iastremska analyzes factors influencing the investment attractiveness of countries in the field of 
tourism. It distinguishes groups of countries with different levels of investment attractiveness in the tourism industry based on the cluster analysis. The research's result is a discriminant analysis, which helps to build a model for evaluating the relationship of indicators of tourism investment attractiveness of each of the selected clusters. It can be useful for Russian regions too (Kozmenko et al., 2015).

O. Kaurova considers groups of measures that make it possible to create economic conditions to attract largescale investments in the sphere of tourism and gives them an investment assessment, as well as recommendations on the introduction of changes into the Tax Code of the Russian Federation (Kaurova, 2013).

V. Krivoruchko and A. Varvashtian describe possible approaches to improving the instruments of the state regulation of tourism. They pay much attention to identifying the problems of interaction between economic entities and state structures in terms of stimulating the development of the tourist complex in the regions, with the proposal of specific methods and mechanisms for their solution (Krivoruchko, Varvashtian, 2011).

Y. Markova believes that one of the main aspects, which increases the flow of investments in the tourist sector of the economy, is a state policy aimed to strengthen tourism activity. In her opinion, positive changes for the Russian economy consist in the creation of tourist and recreational zones with the formation of links in them in the form of tourist clusters as well as in the use of foreign experience (Markova, 2011).
D. Rotanova, M. Vasilyeva and N. Tarabayeva examine the general issues of tax incentives for entrepreneurial activities in Russia (Rotanova, and et., 2016).

However, the problems of the development of domestic tourism and the application of fiscal incentives remain insufficiently developed and need to be revised in view of changes in the domestic and world economies.

Goal of the research is to propose concrete measures of tax stimulation of the domestic tourism industry in Russia to ensure a significant positive growth of the domestic tourist market in the current economic conditions.

\section{THE MAIN RESULTS OF THE STUDY}

The effective development of domestic tourism is of great importance for the Russian Federation, which has a huge natural, climatic, historical and cultural-cognitive potential. According to the strategy for the development of tourism in the Russian Federation for the period until 2020 (Rasporiazhenie Pravitelstva...), the main task is the development and maximum realization of such tourism in Russia, which is regarded as a significant source of financial revenues for budgets of different levels.

Figure 1 shows the dynamics of outbound tourism of the Russian citizens and domestic tourist flows.

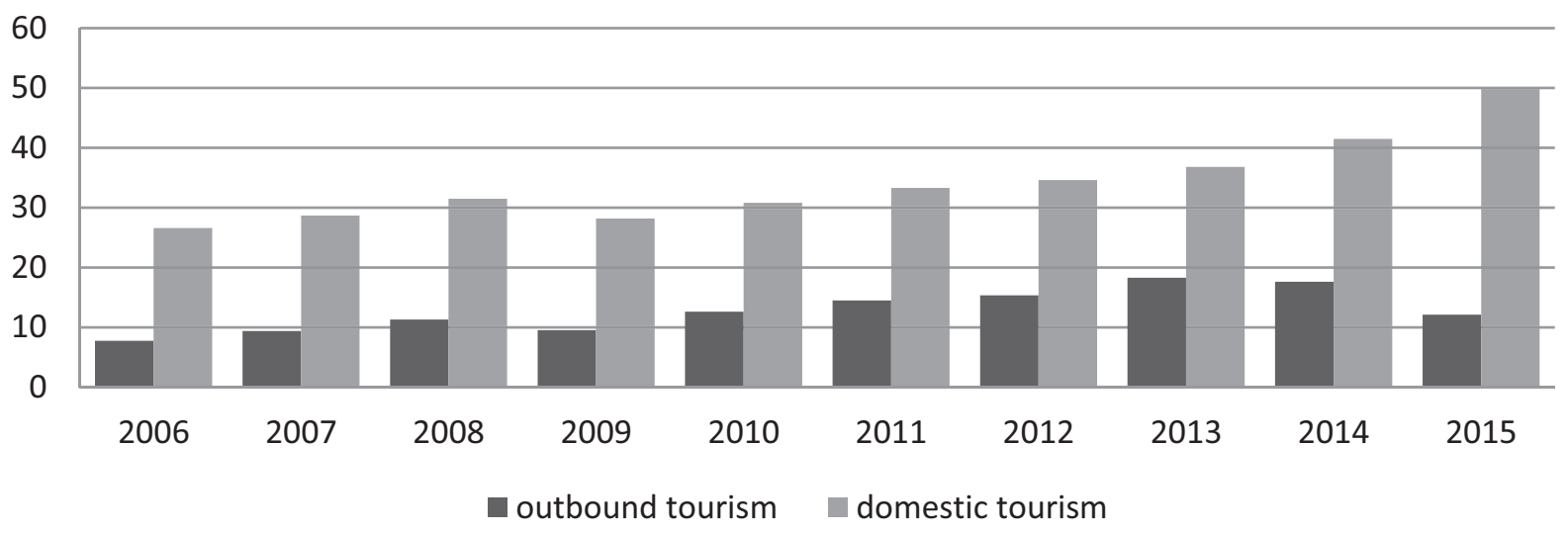

Figure 1. Dynamics of outbound tourism of the Russian citizens and domestic tourist flows over the past 10 years, $\mathrm{mln}$. people, according to the data (Ofitsialnaya statistika...) 
Table 1. Indicators of activities of tourist organizations in Russia, according to the data (Ofitsialnaya statistika ...)

\begin{tabular}{|c|c|c|c|}
\hline Statistical indicators & $\begin{array}{c}\text { Unit of } \\
\text { measurement }\end{array}$ & 2014 & 2015 \\
\hline Number of organizations & Unit & 2823 & 2789 \\
\hline Average number of employees & People & 1043285 & 1273741 \\
\hline $\begin{array}{l}\text { Average number of employees (without part-time workers and } \\
\text { employees, who performed their work under civil law contracts) }\end{array}$ & People & 957730 & 1191740 \\
\hline Average monthly accrued wages of employees & Rubles & 37713 & 40044 \\
\hline Turnover & Bln. Rubles & 1549,8 & 1754,2 \\
\hline Investments into fixed assets & Bln. Rubles & 231,3 & 368,9 \\
\hline Revenues (excluding VAT, excises and similar compulsory payments) & Bln. Rubles & 2531,9 & 2815,3 \\
\hline Profits & Bln. Rubles & 224,7 & 155,0 \\
\hline Losses & Bln. Rubles & 211,7 & 325,4 \\
\hline Balanced financial result (profits minus losses) & Bln. Rubles & 13,0 & $-170,4$ \\
\hline Number of profitable organizations & Unit & 53390 & 62592 \\
\hline Number of unprofitable organizations & Unit & 19354 & 22523 \\
\hline Availability of fixed assets at book value at the end of the year & Bln. Rubles & 349,7 & 2163,0 \\
\hline Availability of fixed assets at residual book value at the end of the year & Bln. Rubles & 255,8 & 1424,9 \\
\hline Putting new fixed assets into operation (yearly value of the indicator) & Bln. Rubles & 97,2 & 163,8 \\
\hline Degree of depreciation of fixed assets at the end of the year & Per Cent & 26,9 & 34,1 \\
\hline Putting new hotels into operation & Beds & 10328 & 11976 \\
\hline $\begin{array}{l}\text { Putting into operation of alternative means of accommodation for } \\
\text { tourists (sanatoria, rest homes, tourist bases, motels, campsites) }\end{array}$ & Beds & 4984 & 1515 \\
\hline
\end{tabular}

The presented dynamics shows that in the recent years, in the Russian Federation, considerable attention has been paid to the state policy in the sphere of domestic tourism. However, with quite impressive growth rates (more than 16 per cent over the last 3 years) of the domestic tourist flows, it is worth noting that in comparison with foreign countries (in the USA up to 80 per cent of the population travels inside the country), this indicator remains low (Bystrov, 2016).

Some indicators of activity of the tourism industry organizations in Russia are presented in Table 1.

According to the information presented at the official press conference of the Executive Director of the Association of Tour Operators of Russia Maya Lomidze on the topic: "The Tourist Industry of Russia: the results of 2016 and the prospects for 2017", the money spent on outbound trips by Russian citizens in the period from 2015 to 2016 fell by 24 per cent (from 4,3 million US dollars to 3,2 million US dollars, respectively), on the other hand, there was a significantly increase by 88 per cent of the expenditures on domestic destinations - from 5,5 million US dollars in 2015 to 10,5 million US dollars in 2016 (Press-konferetsiya ispolnitelnogo direktora Assotsiatsii ...).

Estimation of the demand for services in the sphere of domestic tourism in Russia for the last 4 years is shown in Table 2.

Table 2. Percentage of demand and its quarterly changes for the services of domestic tourism according to the survey of organizations engaged in tourism activities, according to the data (Ofitsialnaya statistika ...)

\begin{tabular}{l|c|c|c|c}
\hline Quarters & Increase & $\begin{array}{c}\text { No } \\
\text { change }\end{array}$ & $\begin{array}{c}\text { Rating } \\
\text { Decrease } \\
\text { balance } \\
\text { (increase- } \\
\text { decrease) }\end{array}$ \\
\hline I quarter & 8 & 55 & 37 & -29 \\
\hline II quarter & 36 & 49 & 15 & 21 \\
\hline III quarter & 38 & 47 & 15 & 23 \\
\hline IV quarter & 18 & 50 & 32 & -14 \\
\hline
\end{tabular}


Table 2 (cont). Percentage of demand and its quarterly changes for the services of domestic tourism according to the survey of organizations engaged in tourism activities, according to the data (Ofitsialnaya statistika ...)

\begin{tabular}{|c|c|c|c|c|}
\hline Quarters & Increase & $\begin{array}{c}\text { No } \\
\text { change }\end{array}$ & Decrease & $\begin{array}{c}\text { Rating } \\
\text { balance } \\
\text { (increase- } \\
\text { decrease) }\end{array}$ \\
\hline \multicolumn{5}{|c|}{2014} \\
\hline I quarter & 11 & 57 & 32 & -21 \\
\hline II quarter & 29 & 49 & 22 & 7 \\
\hline III quarter & 32 & 49 & 19 & 13 \\
\hline IV quarter & 18 & 41 & 41 & -23 \\
\hline \multicolumn{5}{|c|}{2015} \\
\hline I quarter & 11 & 42 & 47 & -36 \\
\hline II quarter & 29 & 45 & 26 & 3 \\
\hline III quarter & 34 & 36 & 30 & 4 \\
\hline IV quarter & 16 & 32 & 52 & -36 \\
\hline \multicolumn{5}{|c|}{2016} \\
\hline I quarter & 13 & 32 & 55 & -42 \\
\hline II quarter & 35 & 32 & 33 & 2 \\
\hline III quarter & 36 & 42 & 22 & 14 \\
\hline IV quarter & 14 & 39 & 47 & -33 \\
\hline
\end{tabular}

It should be noted that there is some similarity between Russia and such leading tourist countries as the United States and China regarding their attractiveness for tourists characterized by favorable geographical location, large territory, natural and climatic diversity, many monuments of historical and cultural significance.

The USA occupies the first place in the world regarding the revenues obtained from tourism (in 2014, 177,2 billion US dollars). Tourism in the US not only amounts to 8 per cent of GDP, but also provides jobs for about 10 per cent of the entire workforce. It is important to note that the biggest share of revenues (up to 80 per cent) is generated not by international tourism, but by the domestic one. The share of domestic tourism in the US is quite high. The most common reasons for traveling inside the country include: visiting relatives and friends, shopping, gastro- nomic trips, beach holidays and visits to national parks. Thus, the US economy is much more tied to domestic tourism than to the out bound one.

Thus, the US economy is more dependent on the domestic tourism than the out bound one (Vnutrenniy turizm kak ...).

The efficiency of the domestic tourism industry in the US is ensured by the country's high level of development, rich recreational resources, successful state policy in the field of tourism and the high level of entrepreneurial spirit of private capital. Despite insignificant financing of tourism from the state budget, its effective development is determined by the positive influence of socially responsible small and mediumsized businesses (small travel agencies, family motels, campsites and catering establishments, eco-farms for tourists, car rental firms, souvenir shops, art workshops, local tour operators, etc.), which have not been properly developed in Russia. At the same time, the development of the domestic tourism industry is influenced not so much by the federal as by state authorities, which have extensive rights (in particular, various forms of stimulation of small business development in this sector). The shortcomings include the absence of a clearly structured system of federal regulation of the sector and the mechanism for realizing its tax incentives.

The PRC (People's Republic of China) is one of the world's top three leaders in revenues from the tourism industry. The share of tourism in the formation of GDP is about 10 per cent. Tourism in China makes it possible to provide employment for about 10 per cent of the entire workforce. At the same time, the share of domestic tourism is more than 70 per cent (Vnutrenniy turizm kak ...).

In China, unlike the United States, there is a comprehensive system of state regulation in the field of domestic tourism. Domestic tourism is becoming increasingly popular in China. Indicators of its growth have been steadily increasing from year to year accompanied by constant monitoring and stimulation from the state (Ob opyte regulirovaniya razvitiya ...). 
To ensure the growth of key indicators of the industry in China, the government of the country carries out a number of activities:

- simplification of rules for accessing the tourism services market, promotion of internationalization of the Chinese tourist companies and development of international cooperation in the field of tourism;

- harmonization of international and domestic standards for the provision of tourism services;

- improvement of domestic, international and regional mechanisms of cooperation in the field of tourism, establishment of interconnected networks of information and service provision to the industry;

- stimulation of charter flights for domestic transportation;

- constant development of new domestic tourist routes;

- stimulation of agrotourism, cognitive tourism, social tourism (in particular, tourism for elderly citizens);

- improvement of transport infrastructure, a system for assessing creditworthiness on the market, financial support for tourism by the state, control over prices for entrance tickets when visiting parks, cultural heritage sites, etc.

The tax policy implemented in the PRC uses the mechanisms of tax stimulation for the domestic tourism industry by means of incentives for small business entities when paying the following taxes: corporate income tax, value added tax, etc.

Thus, the law clearly states that if a taxpayer operates in the tourism sector, the sum of revenues of the tourist firm is a difference between the total amount of revenues (including extra duties) minus the cost of tourist services paid to the host tourist company, as well as the cost of accommodation, meals, transport and entrance fees paid for tourists to other organizations or individuals. Tax rates range according to the type of activity and the category of an enterprise (for example, small taxpayers), which makes it possible to ensure an acceptable level of tax burden on the developing or low profit businesses.

Indisputable positive aspects of the PRC's policy in the field of domestic tourism include a wellcoordinated system of state assistance, a clearly defined list of tasks for long-term development and effectively implemented mechanisms of tax incentives.

In Russia, for many years, domestic tourism traditionally was not given proper attention until significant changes in the conjuncture of the tourist market took place.

In Russia, since 2013, it is the first time that the share of tour operators engaged in domestic tourism exceeds 50 per cent, however, the objective factors of this situation include the reduction in the quality of life of the population, the fall of the national currency and, in the future, the closing of the most popular destinations for outbound tourism.

In order to attract private capital to domestic tourism, state support and incentives are often required (Inskeep, 1997). Since the state currently pays little attention to tax incentives for domestic tourism in Russia, taxation, in its current form, is a significant deterrent to the development of the tourism industry and requires revision of a number of tools and the mechanism of its implementation.

The modern Russian state seeks to create the necessary political and economic climate for successful implementation of market mechanisms, which can make it possible to regulate economic processes in the country, to respond flexibly to the dynamics of the global financial markets and to properly represent the country on the global stage. One of the most effective market mechanisms, which have been firmly established in the theory and practice of state influence on economic processes, is taxation.

Taxes, being a part of the financial and economic system, are a key element of state regulation of the economy. Forming the country's tax system, the 


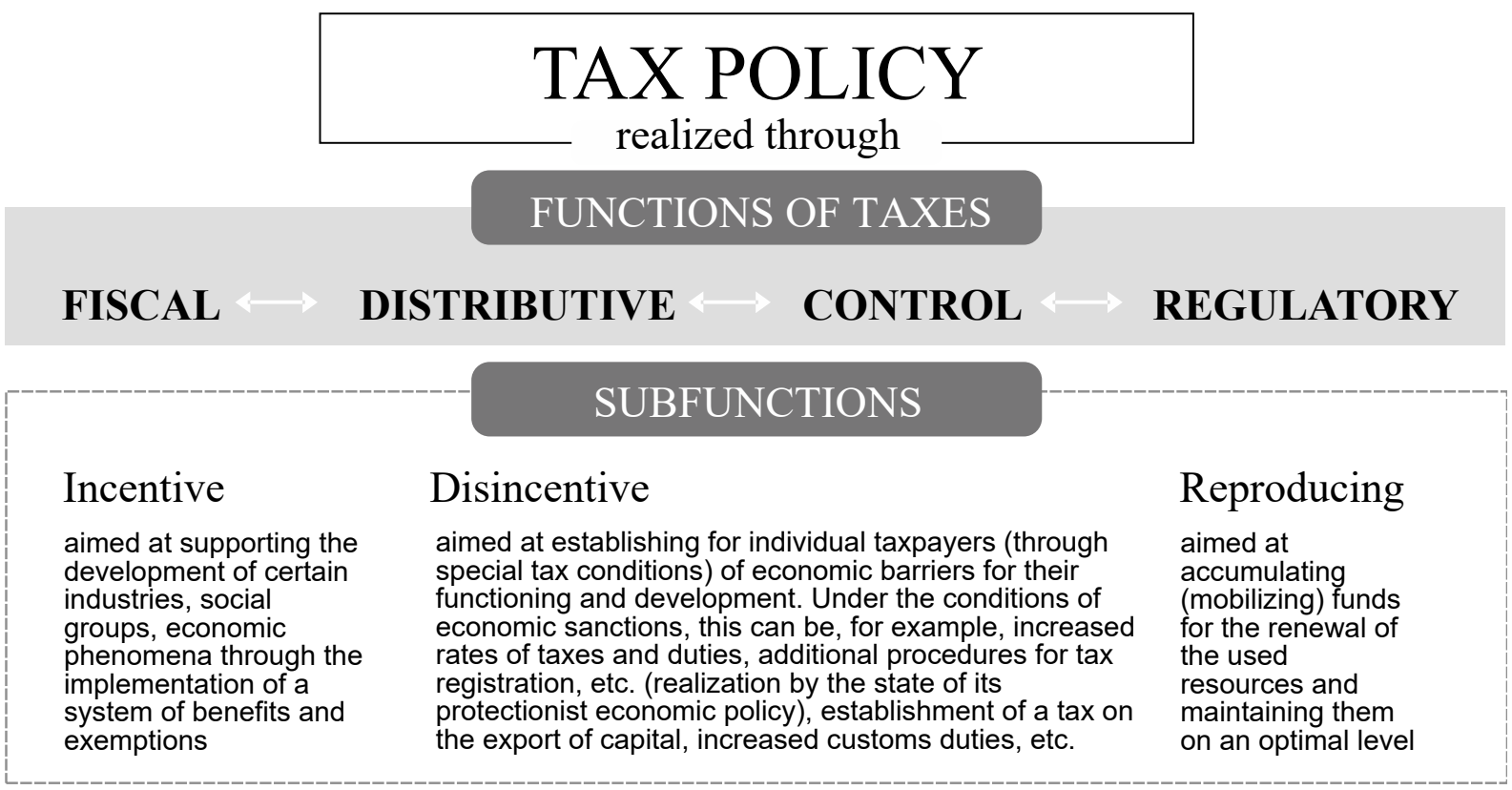

Figure 2. The functions of taxes through which an effective tax policy is realized

state pursues the goal of using it within the framework of the implemented financial policy. In this regard, it becomes a relatively independent sphere - a tax policy, which is a complex of financial, economic and legal measures of the state to create the country's taxation system for the financial pro- vision of activities of the state and certain social groups, for supporting sustainable development of the country's economy by means of distribution and redistribution of financial and other resources. Realization of an effective tax policy is based on interrelated functions of taxes (Figure 2).

Subjects of the tourism market

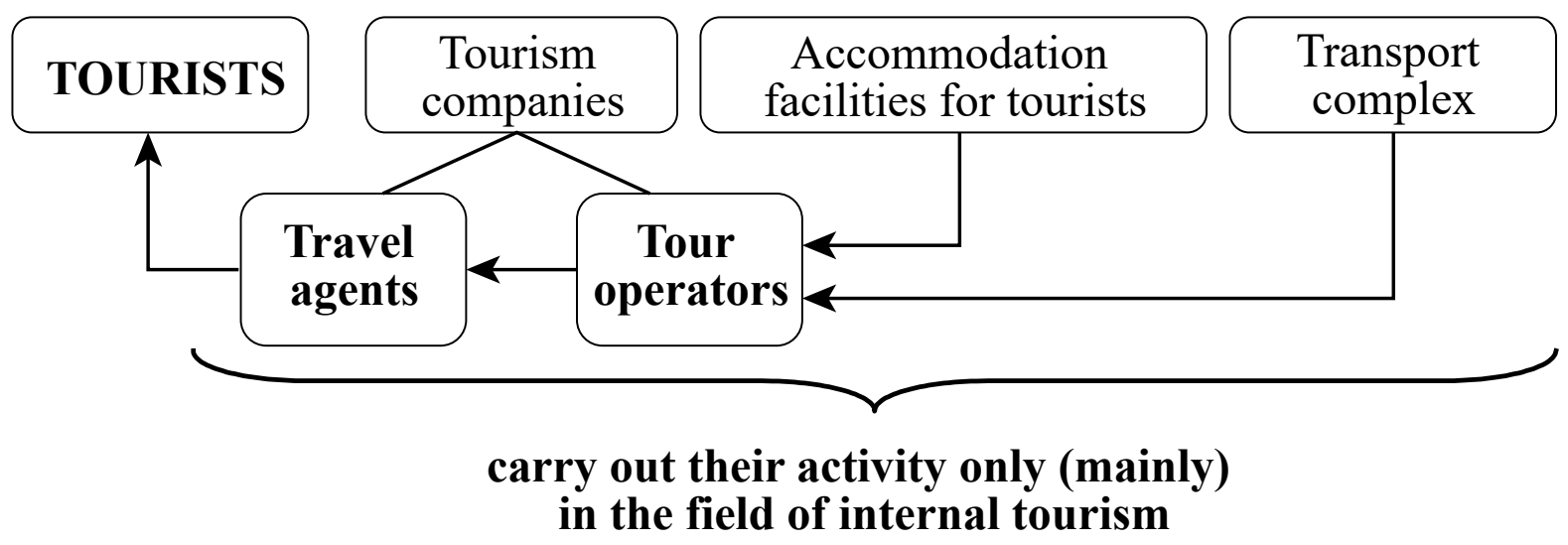

are subject to tax incentives

stimulating legitimate actions in the economic, social and other spheres

Figure 3. Subjects of the tourism market, which are stimulated by tax incentives 


\section{Formation of tourist product}

conclusion and execution of contracts with the third parties that provide certain services included in the tourist product (hotels, carriers, guides, etc.)

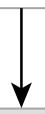

\section{Promotion of tourist product}

a complex of measures aimed at realizing the tourist product (advertising, participation in specialized tourism exhibitions, fairs, organization of tourist information centers, catalogs, etc.)

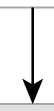

\section{Realization of tourist product}

conclusion of an agreement about the realization of a tourist product with a tourist or other consumer of a tourist product, as well as provision of tourist services in accordance with this agreement

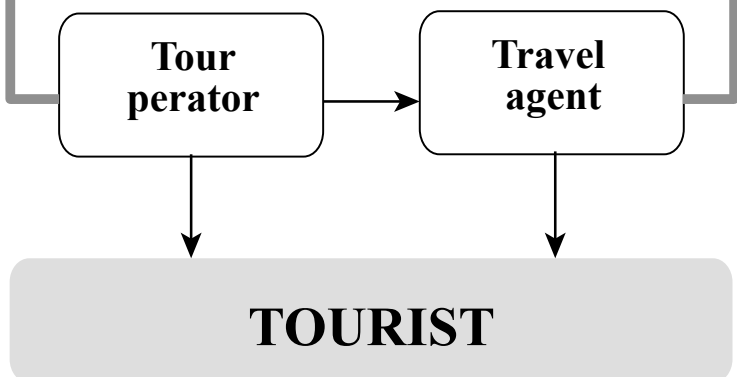

Figure 4. The main stages of creation and bringing the tourist product to the final consumer in Russia

In the modern conditions of functioning of the national economy, which is subject to the impact of crisis phenomena, sanctions and other foreign policy threats, in addition to the fiscal function that realizes the main goal of the tax - the formation of a state monetary fund by withdrawing a share of the income of enterprises and citizens to create material conditions for the functioning of the state and the fulfillment of its own functions, the regulating function and its stimulating subfunction become more and more relevant.

The traditional sectors of the Russian economy, which are stimulated by incentives of the state's tax policy on the federal and regional levels, include agriculture, small and mediumsized businesses, knowledge-based industries, etc. However, the changed economic conditions require from the state to pay attention to other promising industries that need budgetary support, tax privileges and preferences. In particular, domestic tourism is one of the sectors that urgently need state support through tax incentives. Moreover, the foreign policy situation has created all the prerequisites for taking advantage of the current favorable situation and giving impetus to the stimulation and wide dissemination of domestic tourism.

Considering the main components of the tourist product, which largely form its final value for the end users, it seems expedient to divide the subjects of the tourist market, which will benefit from tax incentives, into the categories shown in Figure 3.

One of the most vulnerable subjects of the tourist market are tourism companies, which, in our view, deserve particular attention under the tough conditions of doing business observed in recent years.

Tour operators and travel agents are mutually complementary subjects of the tourist services market, when the activity of a travel agent is impossible without interaction with a tour operator, but not vice versa. Therefore, the bringing of a tourist product to the final consumer can be schematically represented in the following way (Figure 4).

To support enterprises operating in the field of domestic tourism, it is expedient to establish requirements regarding the share of revenues from domestic tourism in their total revenues. Table 3 gives a classification of domestic tourist enterprises and requirements, the compliance with which will enable them to receive state support in the form of tax incentives. 
Table 3. Classification of domestic tourism enterprises

\begin{tabular}{|c|c|c|}
\hline $\mathbf{N}$ & $\begin{array}{l}\text { Type of } \\
\text { enterprise }\end{array}$ & $\begin{array}{c}\text { Requirements and conditions for enterprises } \\
\text { to obtain tax incentives }\end{array}$ \\
\hline 1 & $\begin{array}{l}\text { Accommodation } \\
\text { facilities } \\
\text { for tourists }\end{array}$ & $\begin{array}{l}\text { Carry out their activities and have state registration on the territory of the Russian Federation. Serve } \\
\text { the citizens of the Russian Federation by charging them up to } 80 \text { per cent of the fees established for } \\
\text { persons who do not have Russian citizenship or stateless persons. The revenues in the last financial } \\
\text { year consist of the income from citizens of the Russian Federation (not less than } 25 \text { per cent) both } \\
\text { for accommodation and additional services provided in the accommodation facilities }\end{array}$ \\
\hline 2 & $\begin{array}{l}\text { Food service } \\
\text { establishments } \\
\text { for tourists }\end{array}$ & $\begin{array}{l}\text { Carry out their activities and have state registration on the territory of the Russian Federation. The } \\
\text { revenues in the last financial year consist of the income (not less than } 25 \text { per cent) from servicing } \\
\text { organized tourist groups, in which over } 50 \text { per cent are citizens of the Russian Federation }\end{array}$ \\
\hline 3 & $\begin{array}{l}\text { Recreation } \\
\text { facilities } \\
\text { for tourists }\end{array}$ & $\begin{array}{l}\text { Carry out their activities and have state registration on the territory of the Russian Federation. The } \\
\text { revenues in the last financial year consist of the income (not less than } 50 \text { per cent) from servicing } \\
\text { organized tourist groups, in which over } 50 \text { per cent are citizens of the Russian Federation }\end{array}$ \\
\hline 4 & $\begin{array}{l}\text { Transport } \\
\text { provision } \\
\text { of tourists }\end{array}$ & $\begin{array}{l}\text { Have state registration on the territory of the Russian Federation. Carry out flights to the cities in } \\
\text { Russia, or to the cities in Russia and abroad under the condition that at least } 50 \text { per cent of the } \\
\text { flights cover Russian cities. The revenues in the last financial year consist of the income (not less } \\
\text { than } 25 \text { per cent) from servicing passengers who are Russian citizens and carrying out flights within } \\
\text { the territory of the Russian Federation }\end{array}$ \\
\hline 5 & Tour operators & $\begin{array}{l}\text { Have state registration on the territory of the Russian Federation. The revenues in the last financial } \\
\text { year consist of the income (not less than } 50 \text { per cent) from the sale of tourist products in the field of } \\
\text { domestic tourism to Russian citizens }\end{array}$ \\
\hline 6 & Travel agents & $\begin{array}{l}\text { Carry out their activities and have state registration on the territory of the Russian Federation. The } \\
\text { revenues in the last financial year consist of the income (not less than } 50 \text { per cent) from the sale of } \\
\text { tourist products in the field of domestic tourism to Russian citizens }\end{array}$ \\
\hline
\end{tabular}

We will present the most significant (from the point of view of the authors) measures of tax incentives for the designated categories of the tourist market subjects in the context of domestic tourism in Table 4.

\section{For tourists:}

- introduction of a "recreational deduction" to reduce the tax burden on personal income tax. The size of deduction is determined depending on the time of the year of the tourist trip - 50 thousand Rubles in the period from May 1 to September 30 and 100 thousand Rubles from 1 October to 30 April. Temporary differentiation will help to balance the internal tourist flows reducing the influence of seasonality in some areas and popularizing new forms of recreation.

\section{For tourist firms:}

- formation of a special tax regime, which includes as objects of taxation "revenues in the form of agency fees" at a rate of 5 per cent for travel agents and "revenues minus expenses" at a rate of 10 per cent for tour operators, provided that the income from the sale of the tourism product in the field of domestic tourism amounts to at least 50 per cent with subsequent reduction of the rate by 1 per cent and with an increase in the share by 10 per cent - up to 2 per cent and 7 per cent, respectively.

\section{For accommodation facilities:}

- full exemption from property tax on the property of legal entities and from land tax on new accommodation facilities for a period of 10 years from the moment of their commissioning;

- a 50 per cent reduction on transport tax rates established in the region regarding the vehicles used to service tourists.

\section{For transport complex:}

- application of the VAT rate of 0 per cent for domestic transportation of organized groups of tourists by all types of transport;

- a 50 per cent reduction on transport tax rates established in the region regarding the vehicles used to service tourists.

It is understood that these measures will be implemented on a step-by-step basis with mandatory approbation within the framework of pilot 
projects in the regions with tourist potential (the most attractive destinations, but the least developed in the tourist sense). First of all, this will make it possible to evaluate the economic effectiveness of implementation of measures and adjust their parameters in such a way that they meet the requirements of the industry's development (increase in the internal tourist flows, popularization of recreation within the country, restoration of competitive advantages) and ensuring the profitability of the budgets of the Russian Federation.

Table 4. Proposed measures of tax stimulation for subjects of the tourist market in the context of domestic tourism

\begin{tabular}{|c|c|c|c|c|}
\hline $\mathbf{N}$ & $\begin{array}{l}\text { Legal acts, into which } \\
\text { amendments are } \\
\text { introduced }\end{array}$ & $\begin{array}{l}\text { Agencies, which } \\
\text { are in charge of } \\
\text { this issue }\end{array}$ & Possible risks & Expected results \\
\hline \multirow{3}{*}{1} & \multicolumn{4}{|c|}{$\begin{array}{l}\text { Recreational deductions from personal income tax. The size of deductions is determined depending on the time of the } \\
\text { year of the tourist trip - 50 thousand Rubles in the period from May } 1 \text { to September } 30 \text { and } 100 \text { thousand Rubles from } \\
\text { October } 1 \text { to April } 30\end{array}$} \\
\hline & $\begin{array}{l}\text { Tax Code of the Russian } \\
\text { Federation (addition to } \\
\text { Chapter 23) }\end{array}$ & $\begin{array}{l}\text { Ministry of Finance } \\
\text { of the Russian } \\
\text { Federation }\end{array}$ & \multirow{2}{*}{$\begin{array}{l}\text { The risk of lack of demand for } \\
\text { deductions from the taxpayer } \\
\text { (low taxation culture). The risk } \\
\text { of ambiguous interpretation of } \\
\text { the law by the participants of } \\
\text { tax relations. Additional state } \\
\text { expenditures on the realization } \\
\text { of the tax mechanism and } \\
\text { subsequent tax administration. } \\
\text { The risk of ineffective } \\
\text { application of tax deductions } \\
\text { (excess of expenditures } \\
\text { over revenues from tourism } \\
\text { enterprises) }\end{array}$} & \multirow{2}{*}{$\begin{array}{l}\text { Adaptation of the tax } \\
\text { solution to the current } \\
\text { economic situation. } \\
\text { Reduction of tax burden on } \\
\text { the personal income tax. } \\
\text { Temporary differentiation } \\
\text { will help to balance internal } \\
\text { tourist flows, reduce the } \\
\text { influence of seasonality in } \\
\text { some areas and popularize } \\
\text { new forms of recreation }\end{array}$} \\
\hline & $\begin{array}{l}\text { Methodical } \\
\text { recommendations on the } \\
\text { application of Chapter } 23 \text { of } \\
\text { the Tax Code of the Russian } \\
\text { Federation }\end{array}$ & $\begin{array}{l}\text { Federal Tax Service } \\
\text { of the Russian } \\
\text { Federation }\end{array}$ & & \\
\hline \multirow{5}{*}{2} & \multicolumn{4}{|c|}{$\begin{array}{l}\text { A special tax regime, which includes as objects of taxation "revenues in the form of agency fees" at a rate of } 5 \text { per cent } \\
\text { for travel agents and "revenues minus expenses" at a rate of } 10 \text { per cent for tour operators, provided that the income } \\
\text { from the sale of the tourism product in the field of domestic tourism amount to at least } 50 \text { per cent with subsequent } \\
\text { reduction of the rate by } 1 \text { per cent and with an increase in the share by } 10 \text { per cent - up to } 2 \text { per cent and } 7 \text { per cent, } \\
\text { respectively }\end{array}$} \\
\hline & \multirow{4}{*}{$\begin{array}{l}\text { Tax Code of the Russian } \\
\text { Federation (introduction to } \\
\text { Chapter } 26.6 \text { "The taxation } \\
\text { system for domestic tourism } \\
\text { enterprises") } \\
\text { Methodical } \\
\text { recommendations on the } \\
\text { application of Chapter } 26.6 \\
\text { of the Tax Code of the } \\
\text { Russian Federation } \\
\text { "On the fundamentals of } \\
\text { tourist activities in the } \\
\text { Russian Federation" (addition } \\
\text { to Chapters } 1 \text { and 2) }\end{array}$} & $\begin{array}{l}\text { Ministry of Finance } \\
\text { of the Russian } \\
\text { Federation }\end{array}$ & \multirow{4}{*}{$\begin{array}{l}\text { Information risk (lack of } \\
\text { information, uncertainty). } \\
\text { Risk of the tax process } \\
\text { (misinterpretation of tax } \\
\text { liabilities, errors in tax } \\
\text { accounting and miscalculations } \\
\text { in tax planning). Reputational } \\
\text { risks (formation of negative } \\
\text { notions of stakeholders } \\
\text { about financial stability of } \\
\text { the organization). The risk of } \\
\text { inefficiency of the new tax } \\
\text { regime (problems with tax } \\
\text { administration, the demand } \\
\text { of taxpayers, negative } \\
\text { consequences for the state) }\end{array}$} & \multirow{4}{*}{$\begin{array}{l}\text { Significant simplification of } \\
\text { tax accounting for tourism } \\
\text { organizations. Elimination of } \\
\text { the double interpretation of } \\
\text { the norms of the Tax Code } \\
\text { in connection with the use } \\
\text { of specific concepts in the } \\
\text { field of tourism. Reduction } \\
\text { of the tax burden on travel } \\
\text { agents and tour operators to } \\
\text { stimulate them to develop } \\
\text { and promote domestic } \\
\text { tourism. Stimulation of sales } \\
\text { of the tourist products in the } \\
\text { domestic sector }\end{array}$} \\
\hline & & $\begin{array}{l}\text { Federal Tax Service } \\
\text { of the Russian } \\
\text { Federation }\end{array}$ & & \\
\hline & & $\begin{array}{l}\text { Ministry of Culture } \\
\text { of the Russian } \\
\text { Federation }\end{array}$ & & \\
\hline & & $\begin{array}{l}\text { Federal Agency for } \\
\text { Tourism }\end{array}$ & & \\
\hline \multirow{4}{*}{3} & \multicolumn{4}{|c|}{$\begin{array}{l}\text { Exemption from property tax on the property of legal entities and from land tax on new accommodation facilities for a } \\
\text { period of } 10 \text { years from the moment of their commissioning. A } 50 \text { per cent reduction on transport tax rates established in } \\
\text { the region regarding the vehicles used to service tourists }\end{array}$} \\
\hline & $\begin{array}{l}\text { Tax Code of the Russian } \\
\text { Federation (addition to } \\
\text { Chapters 28, } 30 \text { and 31) }\end{array}$ & $\begin{array}{l}\text { Ministry of Finance } \\
\text { of the Russian } \\
\text { Federation }\end{array}$ & \multirow{3}{*}{$\begin{array}{l}\text { Significant costs on realization } \\
\text { of the tax mechanism and } \\
\text { subsequent tax administration. } \\
\text { The risk of long-term pay-offs } \\
\text { and the possibility of misuse of } \\
\text { tourist infrastructure facilities } \\
\text { for which tax breaks are } \\
\text { established }\end{array}$} & \multirow{3}{*}{$\begin{array}{l}\text { Stimulation of construction } \\
\text { and significant expansion } \\
\text { of accommodation facilities } \\
\text { for tourists, including the } \\
\text { developing tourist centers. } \\
\text { Replacement of fixed } \\
\text { assets (increase in aesthetic } \\
\text { appeal and functionality, } \\
\text { increase in the percentage } \\
\text { of the used accommodation } \\
\text { facilities). Provision of } \\
\text { increased comfort of } \\
\text { passenger transport in } \\
\text { compliance with all safety } \\
\text { requirements through the } \\
\text { acquisition of new vehicles }\end{array}$} \\
\hline & $\begin{array}{l}\text { The laws of the subjects } \\
\text { of the Russian Federation } \\
\text { on taxes (the tax on the } \\
\text { property of organizations } \\
\text { and transport tax) }\end{array}$ & $\begin{array}{l}\text { Executive authorities } \\
\text { of the subjects of the } \\
\text { Russian Federation }\end{array}$ & & \\
\hline & $\begin{array}{l}\text { Legal acts of representative } \\
\text { bodies of municipal entities } \\
\text { on taxes (land tax) }\end{array}$ & $\begin{array}{l}\text { Bodies of local } \\
\text { self-government }\end{array}$ & & \\
\hline
\end{tabular}


Table 4 (cont). Proposed measures of tax stimulation for subjects of the tourist market in the context of domestic tourism

\begin{tabular}{|c|c|c|c|c|}
\hline $\mathbf{N}$ & $\begin{array}{l}\text { Legal acts, into which } \\
\text { amendments are } \\
\text { introduced }\end{array}$ & $\begin{array}{l}\text { Agencies, which } \\
\text { are in charge of } \\
\text { this issue }\end{array}$ & Possible risks & Expected results \\
\hline \multirow{3}{*}{4} & \multicolumn{4}{|c|}{$\begin{array}{l}\text { Application of the VAT rate of } 0 \text { per cent for domestic transportation of organized groups of tourists by all types of } \\
\text { transport }\end{array}$} \\
\hline & $\begin{array}{l}\text { Tax Code of the Russian } \\
\text { Federation (addition to } \\
\text { Chapter 21) }\end{array}$ & $\begin{array}{l}\text { Ministry of Finance } \\
\text { of the Russian } \\
\text { Federation }\end{array}$ & \multirow[t]{2}{*}{$\begin{array}{l}\text { A shortfall in the budget of the } \\
\text { Russian Federation of significant } \\
\text { revenues in the form of VAT. } \\
\text { Risk of misuse of vehicles. Risks } \\
\text { of errors in the calculation } \\
\text { of VAT (the need in separate } \\
\text { accounting) }\end{array}$} & \multirow{2}{*}{$\begin{array}{l}\text { The overall increase in } \\
\text { passenger traffic due to } \\
\text { the reduction in the cost } \\
\text { of transportation services, } \\
\text { including air transportation } \\
\text { of domestic airlines, which } \\
\text { is relevant for the effective } \\
\text { development of the industry. } \\
\text { The release of additional } \\
\text { financial resources, which } \\
\text { can be used to renew } \\
\text { transport fleets }\end{array}$} \\
\hline & $\begin{array}{l}\text { Methodological } \\
\text { recommendations on the } \\
\text { application of Chapter } 21 \text { of } \\
\text { the Tax Code of the Russian } \\
\text { Federation }\end{array}$ & $\begin{array}{l}\text { Federal Tax Service } \\
\text { of the Russian } \\
\text { Federation }\end{array}$ & & \\
\hline
\end{tabular}

\section{CONCLUSION}

The essence of applying incentives in tax relations is the obtaining of deferred financial benefits by the state with a positive social and investment effect. The realization of these measures will contribute to the creation of favorable conditions for the functioning of the domestic tourism industry in Russia, which currently needs state support, tax reliefs and the creation of simplified forms in taxation, accounting and reporting.

The proposed approach to the classification will make it possible to support the enterprises of domestic tourism by stimulating them to increase domestic tourist flows, to promote and popularize the national recreational and cultural sites, to contribute to sustainable development of the whole tourist industry even under the conditions of temporary isolation of the state. In addition, the proposed requirements and conditions can be ranked in proportion to the volume of the obtained tax benefits, which will also make it possible to differentiate enterprises in order to ensure tax fairness.

It is also possible to use the organizational incentive measures, which are already reflected in the federal law of March 2, 2016 № 49-FZ "On amendments to certain legislative acts of the Russian Federation to improve legislation regulating the tourism activity": organization of tourist information centers, lower level of financial provision to domestic tourism compared with outbound tourism, the lack of need for tour operators to form a reserve fund and personal responsibility fund in carrying out activities in the field of domestic tourism, etc.

As a result, the development of domestic tourism in Russia will make it possible to achieve a multiplicative effect: to raise the employment of the population, to create a favorable image of the country, to increase budget revenues, to develop infrastructure and improve the living standards of the population.

\section{REFERENCES}

1. Bystrov, S. A. (2016). Vnutrenniy turizm kak strategicheski vazhnoe napravleniya razvitie turistskogo rynka RF. Nauchnometodicheskiy elektronnyi zhurnal "Kontsept", 15, 966-970.

2. Dmitrieva, E. M., Rokunova, O. V. (2010). Rol gosudarstvennogo regu- lirovaniya $\mathrm{v}$ povyshenii urovnya konkurentosposobnosti Nizhegorodskoi oblasti v sfere turizma. Vestnik Nizhegorodskogo universiteta im. N. I. Lobachevskogo, 3(2), 453-459.

3. Inskeep, E. (1997). National and Regional Tourism Planning: Methodologies and Case Studies.
International Thomson Business Press, 249 p.

4. Kask, S., Kull, T., and Orru, K. (2016). Understanding of sustainable tourism among Russian tourism managers. European Journal of Tourism Research, 14, 101-105. 
5. Kaurova, O. V., Maloletko, A. N (2013). O nalogovom stimulirovanii investitsionnoy aktivnosti gostinichnogo biznesa. Daidzhest-finansy, 8(224), 52-55.

6. Kozmenko, O., Poluliakhova, O., Iastremska, O. (2015). Analysis of countries' investment attractiveness in the field of tourism industry. Investment Management and Financial Innovations, 12(3), 56-63. Retrieved from https:// businessperspectives.org/journals/ investment-management-andfinancial-innovations/issue-100/ analysis-of-countries-investmentattractiveness-in-the-field-oftourism-industry

7. Krivoruchko, V. I. (2011). Sovershenstvovanie instrumentov gosudarstvennogo regulirovaniya turizma. Upravlenie ekonomicheskimi sistemami: elektronnyi nauchnyi zhurnal, 36, 92. Retrieved from http://uecs.ru/uecs-36-122011/ item/882-2011-12-21-12-22-40

8. Krivoruchko, V. I., Varvashtian, A. O. (2011). Formirovanie mekhanizmov stimulirovaniya ekonomicheskogo razvitiya turizma $\mathrm{v}$ regione. Upravlenie ekonomicheskimi sistemami: elektronnyi nauchnyi zhurnal, 36, 116. Retrieved from http://uecs.ru/uecs-36-122011/ item/881-2011-12-21-12-17-25
9. Markova, Yu. A. (2011). Organizatsiya ekonomicheskogo gosudarstvennogo stimulirovaniya razvitiya turistsko-rekreatsionnykh zon na terrirorii Rossiyskoy Federatsii. Regionalnaya ekonomika i upravlenie: elektronnyi nauchnyi zhurnal, 1(25). Retrieved from http://eee-region.ru/article/2504/

10. Ob opyte regulirovaniya razvitiya vnutrennego turizma v Kitae. Retrieved from http://www.russchinatrade.ru/assets/files/ru-useful-info/ domestic_tourism_2015.pdf

11. Ofitsialnaya statistika Federalnoy sluzhby gosudarstvennoy statistiki RF: roznichnaya torgovlya, uslugi naseleniyu, turizm. Retrieved from http://www.gks.ru/ wps/wcm/connect/rosstat_main/

12. Press-konferetsiya ispolnitelnogo direktora Assotsiatsii turoperatorov Rossii Mayi Lomidze na temu: "Turisticheskaya otrasl Rossii: itogi 2016 goda i perspektivy na 2017 god". Retrieved from http:// www.atorus.ru/news/press-centre/ new/37897.html

13. Rasporiazhenie Pravitelstva Rossiyskoy Federatsii ot 31 maya 2014 goda No. 941-p “Ob utverzhdenii Strategii razvitiya turizma v Rossiyskoy Federatsii v period do 2020 goda". Retrieved from http://www.russiatourism. ru/contents/otkrytoe_agentstvo/strategiya-razvitiya-tur- izma-v-rossiyskoy-federatsiiv-period-do-2020-goda-332/ strategiya-razvitiya-turizma-vrossiyskoy-federatsii-v-period-do2020-goda rosstat/ru/statistics/ enterprise/retail/\#

14. Rotanova, D. E., Vasilyeva, M. V., Tarabaeva, N. M. (2016).

Nalogovoe stimulirovanie predprinimatelskoy deyatelnosti. Simvol nauki, 6-1, 257-261.

15. Tribe, J. (2011). The Economics of Recreation, Leisure and Tourism (4th Edition). ButterworthHeinemann, 508 p.

16. Vanhove, N. (2010). The Economics of Tourism Destinations. Routledge, $327 \mathrm{p}$.

17. Vnutrenniy turizm kak sledstvie vneshnei politiki. Retrieved from http://globalaffairs.ru/number/ Vnutrennii-turizm-kak-sledstvievneshnei-politiki-18156

18. Wehrli, R., Egli, H., Lutzenberger, M., Pfister, D., Stettler, J. (2012). Tourist's understanding of sustainable tourism. GSTF Journal on Business Review (GBR), 2(2), 219-224.

19. Yanyushkin, V. A. (2012). Razvitie rynka gostinichnykh uslug $\mathrm{v}$ Rossii. Ekonomika i sovremennyi menedzhment: teoriya i praktika: sb. st. po mater. X mezhdunar. nauch.prakt. konf. Chast II, 137-143. Novosibirsk: SibAK. 